\title{
ANALISIS KEMAMPUAN VO2MAX ATLET SELAM KONI KOTA KEDIRI
}

\author{
Rendhitya Prima Putra \\ Universitas Nusantara PGRI Kediri \\ E-mail: rendhitya@webmail.unpkediri.ac.id \\ DOI: https://doi.org/10.36526/kejaora.v6i1.1300
}

\begin{abstract}
ABSTRAK
Untuk mencapai prestasi yang optimal bagi seorang atlet tentunya terdapat beberapa faktor yang harus diperhatikan, salah satunya adalah kondisi fisik. Cabang olahraga selam merupakan salah satu cabang olahraga yang membutuhkan tingkat daya tahan volume oksigen maksimal yang baik. Tujuan dari penelitian ini adalah menganlisis tingkat volume oksigen maksimal pada atlet selam Koni Kota Kediri. Jenis penelitian ini adalah deskriptif kuantitatif dengan menggunakan metode survei tes dan pengukuran. Teknik penentuan sampel dengan menggunakan total sampling, dengan jumlah keseluruhan 8 orang atlet. Instrumen yang digunakan untuk mengetahui tingkat VO2Max adalah tes MFT. Berdasarkan hasil penelitian dapat diketahui bahwa tingkat VO2Max atlet selam dengan jumlah 8 atlet, berada dalam kategori luar biasa sejumlah 0 atlet $(0 \%)$, kategori sangat baik sejumlah 1 atlet (12.5\%), kategori baik sejumlah 1 atlet (12.5\%), kategori sedang sejumlah 2 atlet $(25 \%)$, kategori kurang sejumlah 1 atlet (12.5\%) dan sangat kurang sejumlah 3 atlet $(37.5 \%)$. Oleh karena itu para pelatih harus menyusun dan memberikan sebuah program latihan guna meningkatkan kapasitas volume oksigen para atlet selam KONI kota Kediri.
\end{abstract}

Kata Kunci: Kondisi Fisik, VO2Max, Atlet Selam

\section{PENDAHULUAN}

Untuk mencapai prestasi yang optimal bagi seorang atlet tentunya terdapat beberapa faktor yang harus diperhatikan, salah satunya adalah kondisi fisik. Sebagaimana pernyataan dari (Mulyadi \& Nikon, 2019) bahwa kondisi fisik merupakan faktor mendasar sebagai penentu suatu prestasi olahraga. Perkembangan prestasi olahraga merupakan hasil dari perpaduan kemampuan fisik, teknik, taktik, mental olahragawan (A. T. Candra, 2016). Oleh karena itu (Utami, 2015) juga berpendapat prestasi yang maksimal dalam olahraga mampu diraih bila latihan diterapkan secara berkualitas, dan menganut konsep pembinaan pramida sebagai proses pencapaian tujuan.

(Supriyoko \& Mahardika, 2018) memgemukakan kondisi fisik yang baik merupakan faktor mutlak yang wajib dimiliki oleh atlet ketika mengembangkan dan meningkatkan prestasi olahraga yang maksimal, sehingga segenap kondisi fisiknya harus dikembangkan dan ditingkatkan.
(Musrifin \& Bausad, 2020) berpendapat kondisi fisik adalah kemampuan seseorang untuk memfungsikan seluruh organ tubuh ketika melakukan seluruh aktivitas fisik dan satu kesatuan utuh dari komponenkomponen yang tidak bisa dipisahkan. Terdapat beberapa komponen kondisi fisik yang perlu diperhatikan dan dikembangkan diataranya adalah daya tahan kardiovaskuler, daya tahan kekuatan, kekuatan otot (strength), kelentukan (flexibility), kecepatan, stamina, kelincahan (agility), daya ledak otot (power),daya tahan kekuatan (strength endurance) (Junaidi, 2019).

Daya tahan merupakan salah satu komponen kondisi fisik yang penting dan bisa dikatakan sebagai pondasi untuk mengembangkan kondisi fisik lainnya (Nugraha, 2017). (O. Candra, 2020) juga berpendapat bahwa daya tahan merupakan kemampuan seseorang untuk menjalankan aktifitas dengan durasi waktu yang lama dan berkesinambungan. Untuk daya tahan kardiovaskular (aerobik) dapat 
Jurnal Kejaora: Jurnal Kesehatan Jasmani dan Olah Raga

ISSN: 2541-5042 (Online)

ISSN: 2503-2976 (Print)

Volume 6 Nomor 1, Edisi April 2021

didefinisikan sebagai kemampuan organisme pada tubuh terutama jantung, paru dan sistem peredaran darah ketika mengatasi kelelahan (A. T. Candra \& Setiabudi, 2021). (Nugraheni et al., 2017) mengemukakan salah satu cara untuk mengetahui daya tahan kardiorespirasi individu adalah dengan mengukur nilai VO2max, yang bertujuan mengukur kinerja kapasitas jantung, paru, dan darah untuk mengangkut oksigen ke otot yang bekerja dan mengukur penggunaan oksigen oleh otot.

Oleh karena itu untuk mempersiapkan diri menghadapi sebuah event dibutuhkan pembinaan kondisi fisik terhadap para atlet. Persiapan kondisi fisik khusus dibangun dengan dasar utama yaitu mempersiapkan atlet untuk menghadapi berbagai event. Tujuan utama dalam pembinaan kondisi fisik khusus adalah untuk memaksimalkan perkembangan unsur unsur kondisi fisik yang lebih spesifik sesuai dengan tuntutan cabang olahraga (Amin \& Adnan, 2020). (Wibisana et al., 2016) juga mengemukakan bahwa kebutuhan kondisi fisik pada masing-masing cabang olahraga tidak dapat disamakan, dikarenakan pada tiap-tiap cabang olahraga memiliki karakteristik gerak masing-masing. Maka dari itu jika seorang atlet bertujuan mencapai prestasi yang maksimal, tentunya faktor kondisi fisik harus ditingkatkan secara bersamaan (Syukur et al., 2019).

Selam merupakan cabang olahraga didalam air dengan menggunakan beberapa peralatan diantaranya berupa monofin atau bifin dan snorkel. Olahraga selam merupakan perkembangan dari olahraga renang. Atlet pada cabang olahraga selam ini dituntut untuk memiliki tingkat kondisi fisik yang baik, terutama pada segi daya tahan (Sugeng \& Iswahyudi, 2020). Lebih spesifik lagi dalam artikel ini akan membahas terkait daya tahan jantung dan paru berdasarkan

volume oksigen maksimal (VO2Max) pada para atlet selam KONI kota Kediri.

\section{METODE}

Penelitian ini berjenis deskriptif dengan pendekatan kuantitatif, dikarenakan data hasil penelitian berupa angka dan menggunakan analisis statistik. Metode yang digunakan yaitu survei dengan teknik tes dan pengukuran. teknik penentuan sampel yaitu dengan menggunakan teknik total sampling dengan keseluruhan atlet selam Koni kota Kediri dengan jumlah 8 orang atlet pada tahun 2021. instrumen yang digunakan untuk mengetahui tingkat volume oksigen para atlet dengan menggunakan tes MFT (Multistage Fitness Tes) atau bleep test (Fenanlampir \& Faruq, 2015).

\section{HASIL DAN PEMBAHASAN}

Berikut ini adalah penyajian data hasil pengukuran tingkat volume oksigan maksimal pada para atlet selam KONI kota Kediri dengan menggunakan instrumen tes MFT. Adapun data hasil penelitian kami sajikan pada tabel dibawah ini:

Tabel 1.Norma Standarisasi Kemampuan VO2Max

\begin{tabular}{lll}
\hline No & Nilai & Kategori \\
\hline 1 & $\geq 52,4$ & Luar Biasa \\
\hline 2 & $46,5-52,4$ & Sangat Baik \\
\hline 3 & $42,5-46,4$ & Baik \\
\hline 4 & $36,5-42,4$ & Sedang \\
\hline 5 & $33,0-36,4$ & Kurang \\
\hline 6 & $\leq 33,0$ & Sangat Kurang \\
\hline (Brianmac, n.d.) &
\end{tabular}

Berdasarkan tabel norma standarisasi kemampuan VO2Max di atas, maka diperoleh deskripsi hasil analisis data dalam bentuk persentase pada tabel dibawah ini:

Tabel 2. Deskripsi Persentase Klasifikasi Tes VO2Max

\begin{tabular}{llll}
\hline Nilai & Frekuensi & Persentase (\%) & Kategori \\
\hline$\geq 52,4$ & 0 & 0 & Luar Biasa \\
\hline $46,5-52,4$ & 1 & 12.5 & Sangat Baik \\
\hline $42,5-46,4$ & 1 & 12.5 & Baik \\
\hline $36,5-42,4$ & 2 & 25 & Sedang \\
\hline
\end{tabular}


Jurnal Kejaora: Jurnal Kesehatan Jasmani dan Olah Raga

ISSN: 2541-5042 (Online)

ISSN: 2503-2976 (Print)

Volume 6 Nomor 1, Edisi April 2021

\begin{tabular}{llll}
\hline $33,0-36,4$ & 1 & 12.5 & Kurang \\
\hline$\leq 33,0$ & 3 & 37.5 & Sangat Kurang \\
\hline
\end{tabular}

Berdasarkan tabel 2 dapat dideskripsikan bahwa tingkat VO2Max atlet selam dengan jumlah 8 atlet, berada dalam kategori luar biasa sejumlah 0 atlet $(0 \%)$, kategori sangat baik sejumlah 1 atlet (12.5 $\%)$, kategori baik sejumlah 1 atlet (12.5\%), kategori sedang sejumlah 2 atlet $(25 \%)$, kategori kurang sejumlah 1 atlet $(12.5 \%)$ dan sangat kurang sejumlah 3 atlet $(37.5 \%)$.

Berdasarkan analisis data hasil tingkat VO2Max dengan menggunakan instrumen tes MFT/bleep test pada atlet PUSLATKOT cabang olahraga selam, dapat dikemukakan bahwa prosentase terbesar berada dalam kategori sangat kurang dengan tingkat persentase $37.5 \%$ sejumlah 3 atlet. Hasil tersebut tentunya merupakan fenomena yang harus di perhatikan dan ditindak lanjuti secara serius oleh para pelatih dan atlet.

Volume oksigen maksimal merupakan salah satu parameter bagi para atlet terkait pencapaian prestasi mereka. Ketika atlet memiliki tingkat VO2Max yang baik maka mereka juga akan mampu menunjukkan performa yang terbaik. Sebagaimana pernyataan (Tumiwa et al., 2016) bahwa atlet yang memiliki tingkat VO2Max baik akan mampu tampil prima dengan kemampuan terbaiknya. Bagi seorang atlet daya tahan tubuh sangat dibutuhkan, agar dalam setiap pertanding mereka mampu bertahan dalam waktu yang cukup lama (S.R \& Rismayanthi, 2016).

Oleh karena itu para pelatih harus menyusun dan memberikan sebuah program latihan guna meningkatkan tingkat volume oksigen para atlet selam KONI kota Kediri. Tingkat kebugaran jasmani dengan tolak ukur VO2Max akan meningkat bila diberikan suatu pelatihan fisik yang teratur, terukur, terprogram dan beban berlebih (Nirwandi, 2017).

\section{KESIMPULAN}

Berdasarkan pembahasan data hasil penelitian diatas, maka dapat disimpulkan bahwa tingkat daya tahan volume oksigen maksimal para atlet selam dominan berada pada kategori sangat kurang dengan tingkat persentase $37.5 \%$ sejumlah 3 atlet. Oleh karena itu penulis merekomendasikan kepada para pelatih untuk memberikan program latihan kondisi fisik kepada para atlet guna meningkatkan daya tahan volume oksigen maksimal mereka.

\section{DAFTAR PUSTAKA}

Amin, H., \& Adnan, A. (2020). Studi Tentang Beberapa Komponen Kondisi Fisik Atlet Bolavoli Smk Negeri 1 Kota Solok. Jurnal Patriot, 2(1), 265-276.

Brianmac. (N.D.). Pengaruh Interval Training Terhadap Vo2max Atlet Ukm Gulat Universitas Negeri Surabaya Lazoardy Zola Septian. Retrieved April 7, 2021, From Http://Brianmac.Co.Uk/Beep:Htm

Candra, A. T. (2016). Studi Tentang Kemampuan Lompat Tegak Siswa Sekolah Dasar Negeri Berdasarkan Perbedaan Geografis Sebagai Identifikasi Bakat Olahraga. Jurnal Sportif, 2(2), 1-14.

Candra, A. T., \& Setiabudi, M. A. (2021). Analisis Tingkat Volume Oksigen Maksimal (Vo2max) Camaba Prodi Pjkr. Jurnal Pendidikan Kesehatan Rekreasi, 7(1).

Candra, O. (2020). Tingkat Kemampuan Vo2max Pada Atlet Bola Basket Puteri Pomnas Riau. Journal Sport Area, 5(2), 106-115.

Fenanlampir, A., \& Faruq, M. M. (2015). Tes \& Pengukuran Dalam Olahraga. Cv. Andi Offset.

Junaidi, S. (2019). Metode Latihan Bermain Untuk Meningkatkan Power Otot Tungkai Atlet Bolavoli Pada Tim Pervik Kediri Tahun 2018. Journal Of Sport And Exercise Science, 2(1).

Mulyadi, H., \& Nikon, B. (2019). Tinjauan Kondisi Fisik Atlet Bola Basket. Jurnal Pendidikan Jasmani Dan Olahraga, 2(2), 26-32.

Musrifin, A. Y., \& Bausad, A. A. (2020). Analisis Unsur Kondisi Fisik Pemain Sepak Bola Mataram Soccer Akademi Ntb. Jurnal IImiah Mandala Education, 
Jurnal Kejaora: Jurnal Kesehatan Jasmani dan Olah Raga

ISSN: 2541-5042 (Online)

ISSN: 2503-2976 (Print)

Volume 6 Nomor 1, Edisi April 2021

6(1), 113-119.

Nirwandi. (2017). Tinjauan Tingkat Vo2max Pemain Sepakbola Sekolah Sepakbola Bima Junior Kota Bukittinggi. Jurnal Penjakora, 4(2).

Nugraheni, H. D., Marijo, \& Indraswari, D. A. (2017). Perbedaan Nilai Vo2max Antara Atlet Cabang Olahraga Permainan Dan Bela Diri. Jurnal Kedokteran Diponegoro, 6(2), 622631.

S.R, A. D., \& Rismayanthi, E. (2016). Profil Tingkat Volume Oksigen Maskimal (Vo2 Max) Dan Kadar Hemoglobin $(\mathrm{Hb})$ Pada Atlet Yongmoodo Akademi Militer Magelang. Jurnal Olahraga Prestasi, 12(2).

Sugeng, I., \& Iswahyudi, N. (2020). Profil Daya Tahan Kardiorespirasi Vascular Atlet Putri Finswimming Ku C Dan D Dragon Wira Yudha Kota Kediri Tahun 2019. Jurnal Buana Pendidikan, 29.

Supriyoko, A., \& Mahardika, W. (2018). Kondisi Fisik Atlet Anggar Kota Surakarta. In Jurnal Sportif (Vol. 4, Issue 2).

Syukur, M. R., Budiarto, \& Kastrena, E. (2019). Kontribusi Daya Ledak Otot Lengan Dan Daya Ledak Otot Tungkai Terhadap Hasil Smash. Jurnal Maenpo, 09(1), 23-29.

Tumiwa, H. T., Rattu, A. J. M., \& Paul A T Kawatu. (2016). Gambaran Kapasitas Vital Paru Dan Volume Oksigen Maksimum ( Vo2max ) Pada Atlet Sepak Bola Ps. Bank Sulutgo Di Kota Manado Tahun 2016. Jurnal IImiah Farmasi, 5(2), 251-258.

Utami, D. (2015). Peran Fisiologi Dalam Meningkatkan Prestasi Olahraga Indonesia Menuju Sea Games. Jurnal Olahraga Prestasi, 11(2), 52-63.

Wibisana, F., Rinaldy, A., \& Nusufi, M. (2016). Evaluasi Kondisi Fisik Dominan Pada Atlet Karate-Do Dojo Lanal Inkai Kota Sabang Tahun 2015. Jurnal IImiah Mahasiswa Pendidikan Jasmani, Kesehatan Dan Rekreasi, 2(1), 82-89. 